Complementary

Medicine Research

Practice $\mid$ Methods|Perspectives
Published online: June 19, 2017

\title{
Complementary Medicine: A Serious Option as We Are Facing the Problem of Bacterial Antibiotic Resistance
}

\author{
Harald Walach ${ }^{\mathrm{a}, \mathrm{b}}$ \\ a Department of Psychology, University of Witten-Herdecke, Witten, Germany; \\ ${ }^{b}$ Department of Pediatric Gastroenterology, Medical University of Poznan, Poznan, Poland
}

I used to work at the Institute of Environmental Medicine and Hospital Epidemiology with the University Hospital in Freiburg. The institute's former director, Franz Daschner, a celebrity in antibiotics, had established a research group evaluating complementary medicine, which I was heading at that time. Nearly 20 years ago, I had started to work there and learned a lot about antibiotics and their relationship with resistance, and already then it became pretty clear to me that our therapeutic options to fight bacteria were not only poor, but also the therapeutic reasoning on which it was based was essentially flawed. It is not that antibiotics are useless or do not work. Not at all: they both work and can be life-saving. But what became clear to me was the 'triple fallacy' that (i) bacteria (and viruses) are causes of diseases in the proper, scientific, and philosophical sense of the word, (ii) that fighting bacteria is the best therapeutic option, and (iii) that this fight can be won. All 3 propositions are very likely wrong. Add to this the fourth problem: (iv) that our overemphasis on hygiene - using disinfectants, anti-microbial washes, and anti-bacterial this and that - creates the very problem it is designed to solve.

Perhaps reminding ourselves of a few basics of microbiology is useful here: most bacteria come in colonies and live together. They have been around some billions of years earlier than any other life on earth, and they will likely still be around when we are long gone. Our cells are functional and effective precisely because many million years ago, single-cell organisms went into a symbiosis with bacteria out of which evolved cells like ours: including former bacteria, namely mitochondria - hundreds, even thousands of them per cell -, that produce the energy we live on. In other words, higher organisms such as warm blooded animals like us would not even have been possible without the energy supply they are harvesting from bacteria that they have at some point included into their biological make-up. Our gut and our skin, in addition to the mitochondria of our cells, are home to an order of magnitude of more bacteria than we have cells in our body. Thus, biologically speaking, we are more like vehicles, homes, and vectors for bacteria. And far from them being a nuisance, we could not even live without them. In the gut, they produce important nutrients, such as B-vitamins, vitamin $\mathrm{K}$, short-chain fatty acids from complex carbohydrates, as nourishment for us and themselves. Only since a few years, we have been receiving data on how important an undisturbed microflora of the gut is for our health and wellbeing. Autoimmune diseases, obesity, and digestive problems seem to be associated with a disturbed microflora, and the overuse of antibiotics is one of the major disturbing factors here $[1,2]$. Bacteria can live in sulfuric geysers in Iceland and on the bottom of the sea. They have been discovered in arctic climates as well. If they come under threat from unto-

\section{KARGER}

() 2017 S. Karger GmbH, Freiburg

Fax +497614520714 
ward circumstances, such as the use of antibiotics, they can retract into sleeping forms like cysts, in which they can wait out any threat until they can thrive and proliferate again. Their proliferation cycle is so quick that there will always be the odd chance mutation being able to survive whatever killer the bacteria are confronted with. And to make things even more complicated, they can exchange resistance genes among each other, just as if soldiers under threat in a war were to help each other out with shields and shelter. Now, how can we, in all seriousness, think that this biological reality is for us to meddle with, and that 'fighting' bacteria is an intelligent way of dealing with disease as a rule and a general principle? All we can do is learn to intelligently live with them and make use of their potential, while at the same time learn to avoid dangers.

To be clear, there are situations where antibiotics and fighting bacteria are the best and the only solution to a medical problem: whenever the host organism is too weak or too severely injured, when sepsis is impending, when host defenses are compromised by interventions or disease, when severe diseases or lasting handicaps are lurking around the corner. In short: in severe and acute cases, we should be happy and glad to have invented antibiotics. The problem is, however, that the actual usage of antibiotics is far from intelligent. They are used a lot in pediatrics to assuage parents' anxieties in childhood infectious diseases, the majority of which are viral and not bacterial in nature, thus, antibiotics being not more than a potentially dangerous placebo not generally benefiting the patient and producing risks of severe bowel diseases later in life [3-5]. More than $70 \%$ of antibiotics are not prescribed in emergency medicine, but in general practice - to calm patients, as a preventive, or because the practitioners have no better idea. Counseling doctors to use antibiotics sparingly has proven to be not very effective [6]. This is so despite the fact that most recent studies in general practice show that antibiotics are overprescribed. Even in situations where they are indicated, their actual clinical effectiveness is minute [7]. For instance, a bacterially caused upper respiratory tract infection, which would last a full week, is only shortened by half a day when antibiotics are used, and the severity of the symptoms is hardly affected at all. We also know that a frequent usage of antibiotics, e.g., in urinary or respiratory tract infections, is associated with more frequent recurrences and, this is no surprise, with resistance of the strains of bacteria that are considered the 'cause' of the disease [8]. I deliberately put 'cause' in inverted commas because calling bacteria the cause of a disease is to some extent logically and conceptually arbitrary. Why is the contact with bacteria, that are ubiquitous anyway, considered the cause of, say, an upper respiratory tract infection or of pneumonia, and not the severe stress someone might have had previously or the loss of a loved one? Why do bacteria count as cause, but not the lack of resistance in a child or an adult, when an overemphasis on hygiene might even compromise the immune system [9]? Well, the answer to these questions is as simple as it is arbitrary: bacteria count as causes because they can be materially isolated and because they can be supposedly dealt with, e.g., by antibiotics.

It was surely a breakthrough when Robert Koch and others discovered bacteria as the root cause for tuberculosis. But his postu- lates - that all cases show these associations, and that contact with these agents invariably causes disease - have long been proven wrong in their stringency $[10,11]$. There are many people who come in contact with bacteria, even dangerous ones, or are silent hosts to them, and never experience any overt symptoms or disease. Even resistant strains of bacteria can live on people «happily» without them ever knowing about their guests or suffering from any symptoms. Koch's breakthrough was more of a conceptual and scientific nature than it was of therapeutic use. As the data published by McKeown [12] show: the incidence figures of tuberculosis were declining linearly and gradually long before Koch discovered the tuberculosis bacterium, and the introduction of vaccination or the discovery of antibiosis did nothing to change that trajectory. McKeown's argued that the major drivers of health were hygiene in general terms and social progress, with better food, better housing, better sanitation, and better water supply for the majority of people. In other words: the key aspect for improving health was actually host defense, not the fight against bacteria. Modern medicine was born out of emergency treatments and is following another narrative. It is emphasizing all those fights against acute diseases - among them severe infections - that were successful. This is natural and also conceptually right. However, we should not forget that these are the exceptions, not the rule. The rule is: a strong host is the best defense against infection, and the cause of an infection is not an invading bacterium but a weak host. The fact that it is more convenient and also more successful to target the bacterium in case of an acute disease should not make us forget that the host's susceptibility is the true cause of the disease, except in very rare cases where there is no natural immunity or bacteria are so aggressive that the immune reaction is insufficient or itself deadly, as was the case in the large epidemics of pestilence, cholera, and others.

Therefore, it is not surprising that the use and abuse of antibiotics, the dilemma of antibiotic treatment and the options offered by complementary medicine - as important subthemes - ran like a thread through this year's joint meeting of the European Conference of Integrative Medicine (ECIM) together with the International Society of Complementary Medicine Research (ISCMR) that was held in Berlin from May 3-5 (World Congress on Integrative Medicine \& Health 2017). Starting with Margaret Chan, the outgoing Secretary of the World Health Organization (WHO), and followed by a series of plenary speakers and a specialized workshop, the information provided for the audience, some of which I have summarized above, was clear: antibiotic resistance is going to be a major public health problem for the world in the future, and there are no good strategies ahead. Pharmaceutical companies have no incentives to develop ever more sophisticated antibiotics, which will be very costly and complicated in the face of the fact that they, too, will meet with resistant bacteria further down the line. Even now, many strands of bacteria are resistant to most antibiotics on the market. There is little prospect of the biggest drivers of antibiotic resistance being stopped: preventive and anabolic usage of antibiotics in animal farming - preventive in Europe and anabolic in the rest of the world -, and misuse of antibacterial disinfectants for hygiene and antibiotics for trivial health problems. 
From this perspective, complementary treatments (should) come into the picture. As a series of interesting talks at the World Congress showed, nearly all complementary therapies, phytotherapeutic, naturopathic, or other, are not targeting bacteria as a threat and a cause of disease, but are helping host defenses. They work by improving natural immunity, like sauna and water applications, or by boosting immune processes, like various phytotherapeuticals. Even homeopathy might have a role to play, as it seems to help host responses [13-15]. Although many of these approaches are badly studied and we have not enough data on them, they seem to provide a natural alternative road ahead. And the research com- munity might want to actually accept the challenge that is posed by various institutions, the European research agenda, the WHO, and other large entities, by providing good research protocols and alternative routes out of the antimicrobial conundrum, namely by focusing on host resistance instead on fighting bacteria. It would be helpful if the more enlightened parts of the mainstream press stopped their CAM bashing in the face of the joint threat that conventional approaches are partly responsible for - the bacterial resistance epidemic that is about to make itself felt and points to the obvious way forward: more research on promising approaches that improve host resistance and defenses.

\section{References}

1 Willing BP, Russell SL, Finlay BB: Shifting the balance: antibiotic effects on host-microbiota mutualism. Nat Rev Microbiol 2011;9:233-243.

2 Komaroff AL: The microbiome and risk for obesity and diabetes. JAMA 2017;317:355-356.

3 Williams G, Craig JC: Long-term antibiotics for preventing recurrent urinary tract infection in children. Cochrane Database Syst Rev 2011;(3):CD001534.

4 Hviid A, Svanström H, Frisch M: Antibiotic use and inflammatory bowel disease in childhood. Gut 2011;60: 49-54.

5 Fahey T, Stocks N, Thomas T: Systematic review of the treatment of upper respiratory tract infection. Arch Dis Child 1998;79:225-230.

6 Hemkens LG, Saccilotto R, Reyes S, Glinz D, Zumbrunn T, Grolimund O, Gloy V, Raatz H, Widmer A, Zeller A, Bucher HC: Personalized prescription feedback using routinely collected data to reduce antibiotic use in primary care: a randomized clinical trial. JAMA Intern Med 2017;177:176-183.
7 Little P, Moore MV, Turner S, Rumsby K, Warner G, Lowes JA, Smith H, Hawke C, Leydon G, Arscott A, Turner D, Mullee M: Effectiveness of five different approaches in management of urinary tract infection: randomised controlled trial. BMJ 2010;340:c199.

8 Costelloe C, Metcalfe C, Lovering A, Mant D, Hay AD: Effect of antibiotic prescribing in primary care on antimicrobial resistance in individual patients: systematic review and meta-analysis. BMJ 2010;340:c2096

9 Lluis A, Depner M, Gaugler B, Saas P, Casaca V, Raedler D, Michel S, Tost J, Liu J, Genuneit J, Pfefferle P, Roponen M, Weber J, Braun-Fahrländer C, Riedler J, Lauener R, Vuitton DA, Dalphin JC, Pekkanen J, von Mutius E, Schaub B; Protection Against Allergy: Study in Rural Environments Study Group: Increased regulatory T-cell numbers are associated with farm milk exposure and lower atopic sensitizationn and asthma in childhood. J Allergy Clin Immunol 2014;133:551-559.
10 Evans AS, Feldman HA (eds): Bacterial Infections of Humans: Epidemiology and Control. New York, Plenum, 1982.

11 Benenson AS: Cholera; in Evans AS, Feldman HA (eds): Bacterial Infections of Humans: Epidemiology and Control. New York, Plenum, 1982, pp 187-206.

12 McKeown T: Die Bedeutung der Medizin: Traum, Trugbild oder Nemesis? Frankfurt, Suhrkamp, 1982 orig. 1979.

13 Szőke H, Maródi M, Sallay Z, Székely B, Sterner MG, Hegyi G: Integrative versus conventional therapy of chronic otitis media with effusion and adenoid hypertrophy in children: a prospective observational study. Forsch Komplementmed 2016;23:231-239.

14 Colas A, Danno K, Tabar C, Ehret J, Duru G: Economic impact of homeopathic practice in general medicine in France. Health Econ Rev 2015;5:55.

15 Fätkenheuer G, Hirschel B, Harbarth S: Screening and isolation to control meticillin-resistant Staphylococcus aureus: sense, nonsense and evidence. Lancet 2015;385: 1146-1149. 